\title{
EREBEA
}

Revista de Humanidades y Ciencias Sociales

NúM. 10 (2020), pp. 15-30

ISSN: 0214-0691

http://dx.doi.org/10.33776/erebea.v10i0.4954

\section{Being Positive, Participative and Flexible: tools to HUMAN DEVELOPMENT AND PROGRESS}

\author{
Margarida Gaspar de Matos 1,2,3 \\ Gina Tomé ${ }^{1,2}$ \\ Cátia Branquinho ${ }^{1,2}$ \\ Marta Reis ${ }^{1,2}$ \\ Lúcia Ramiro ${ }^{1,2}$ \\ Diego Gomez-Baya ${ }^{1,2,4}$ \\ Tania Gaspar ${ }^{1,5}$ \\ ${ }^{1}$ University of Lisbon, ISAMB \\ ${ }^{2}$ University of Lisbon, FMH \\ ${ }^{3}$ Ispa, APPSYci \\ ${ }^{4}$ University of Huelva \\ ${ }^{5}$ University Lusíada de Lisboa, CLISSIS
}

AbSTRACT

Over the past two decades, it was largely recognized in the literature that youth programs and interventions would have limited impact if they mainly focused on risks and vulnerabilities. Strengthbased approaches have been found to be empowering and effective in various contexts and theinterest in preventing youth problems and promoting healthy youth development has led practitioners, policy makers and researchers to develop a wide range of approaches drawn from several theoretical frameworks. Contemporary models of youth development and problem prevention can be generally grouped into one of three types: prevention, resilience, and positive youth development. Each approach gives a unique contribution to the knowledge on coping, development,

\section{RESUMEN}

Durante las últimas dos décadas, se ha reconocido en gran medida en la literatura que los programas e intervenciones para jóvenes tendrían un impacto limitado si se enfocaran sólo en los riesgos y vulnerabilidades. Se ha encontrado que los enfoques basados en las fortalezas empoderan y son efectivos en varios contextos, y el interés en prevenir los problemas de la juventud y en promover el desarrollo saludable de los jóvenes ha llevado a los profesionales, los responsables políticos y los investigadores a desarrollar una amplia gama de enfoques extraídos de varios marcos teóricos. Los modelos contemporáneos de desarrollo juvenil y de prevención de problemas se pueden agrupar generalmente en tres tipos: prevención, resiliencia y desarrollo positivo juvenil. Cada enfoque brinda una contribución única al conocimiento sobre 
human adaptation, and thriving, and they all share several key features and a common vision focused on improving the life of youths. Furthermore, models focusing on Positive Youth Development (PYD) pointed out that "PYD" means either developmental processes, or a philosophy to address young people thriving or, finally, the development of programs promoting healthy and positive development in youth. Yet, links and synergies are missing among these three perspectives. More recently, integrative models were developed, having the potential benefit of interconnectedness of risk, protection and assets, within the ecological systems affecting human development, and highlighting the role and the power of the ecosystems in the possibility of change, thus increasing health and well-being, the sense of purpose, fulfillment and thriving. Furthermore, in a period of rapid changes, being happy and not feeling "irrelevant" has to do with being able to deal with diversity and change, maintaining and developing curiosity, and openness to changes and psychological flexibility, thus considering change and diversity as opportunities. The purpose of the present work is to give a guided tour around theoretical frameworks and research that ground this conceptual historical development.

KeYwords

Prevention; Promotion; Positive development; Resilience; Self-regulation; Thriving; Psychological Flexibility; Integrative models

Fecha de recepción: 24 de septiembre de 2020 Fecha de aceptación: 26 de octubre de 2020 el afrontamiento, el desarrollo, la adaptación humana y la prosperidad, y todos comparten varias características claves y una visión común centrada en mejorar la vida de los jóvenes. Por otra parte, los modelos que se enfocan desde el Desarrollo Positivo Juvenil (DPJ) pueden implicar el estudio de los procesos evolutivos, una filosofía para abordar el desarrollo próspero de los jóvenes o bien el diseño de programas que promueven un desarrollo saludable y positivo en la juventud. Sin embargo, falta aún construir vínculos y sinergias entre estas tres perspectivas. Más recientemente, se han desarrollado los modelos integradores que tienen el beneficio potencial de la interconexión de riesgo, protección y activos, dentro de los sistemas ecológicos que afectan el desarrollo humano, y destacan el papel y el poder de los ecosistemas en la posibilidad de cambio, aumentando así la salud y el bienestar, el propósito vital, la autorrealización y la prosperidad. Además, en un período de cambios rápidos, ser feliz y no sentirse "irrelevante" tiene que ver con ser capaz de afrontar la diversidad y el cambio, mantener y desarrollar la curiosidad, la apertura a los cambios y la flexibilidad psicológica, considerando así el cambio y la diversidad como oportunidades. El propósito del presente trabajo es ofrecer un revisión de los marcos teóricos y de investigación que fundamentan este desarrollo histórico conceptual.

Palabras Clave

Prevención; Promoción; Desarrollo positivo; Resiliencia; Autorregulación; Prosperidad; Flexibilidad psicológica; Modelos integradores

\section{ACKNOWLedgments:}

To Nora Wiium and the other colleagues from PYD international: http://www. uib.no/en/rg/sipa/pydcrossnational for all support and inspiration, and colleagues from Aventura Social www.aventurasocial.com for a lifelong collaboration. 


\section{The Context}

The research team Aventura Social (Social Adventure/SA http://aventurasocial. com/index.php) began in 1987, and since then it has developed several studies on health and well-being promotion and social behaviour in children and adolescent health, using empirical tools to collect data and to develop and evaluate field interventions. SA is involved in several international projects and regularly collaborates with Portuguese policy-makers and the Portuguese media. The initial project, Social Adventure \& Risk, consisted on the evaluation of programs for the promotion of interpersonal communication and competence in closed institutions (juvenile offenders' centres, special education needs centres or vulnerable children and youth centres), as a means to prevent risk behaviours, namely violence and substance use. The second group of projects Social Adventure of Health was integrated in several European/international networks such as the Health Behaviour in School Aged Children (HBSC/WHO) and focus on health promotion research, aiming at having impact on health education policies, throughout a better understanding of health-related behaviours and their contexts. The last group of projects Social Adventure \& Community was developed to offer a health and well-being promotional structure, through the activation of community resources and promotion of people's participation and engagement (Matos \& Simóes, 2016).

From 2014 on, the SA team was pioneer in the implementation of a nationwide project called Dream Teens aiming at enhancing young people's participation and active citizenship in the Portuguese context. The Dream Teen project used an innovative Positive Youth Development approach that engaged Portuguese youth (aged 11-18 years) through social media tools, in order to facilitate their civic engagement and development. Participants from all over the country were empowered (1) to design and conduct research activities about their behaviours and about their life contexts and (2) to create ways to improve youth civic participation in their communities, while developing supportive interactions with adults and peers (Matos et al, 2015; Branquinho \& Matos, 2018). A few other projects were derived from this, either developing youth positive development and participation throughout their empowerment by local authorities (Dream Teens Powered by Cascais municipality), either developing the positive engagement in other age groups (The Dream Kids and the Dream 
Old) or intergenerationally (\#GenerationsWithAVoice), or finally developing healthy, positive and participative schools' ethos (EsABE- Ecosystems of learning and well-being) (check all projects: methods, participants and results at www. aventurasocial.com)

\section{Positive Youth Development and social engagement}

Over the past couple of decades, the study of adolescence has been essentially focused on a "deficit perspective" characterized by the objective to decrease problems. This perspective has influenced policies, research and practices, and youth development was characterized by the identification of what youths should avoid, rather than identifying indicators of positive development or well-being (Moore, Lippman, \& Brown, 2004).

Later, it was largely recognized in the literature that youth programs and interventions would have limited impact if they mainly focused on risks and vulnerabilities. Strength-based approaches have been found to be empowering and effective in various contexts (Benson, Scales, Hamilton, \& Sesma, 2006) and the interest in preventing youth problems and promoting healthy youth development has led practitioners, policy-makers and researchers to develop a wide range of approaches relying on several theoretical frameworks (Small \& Memmo, 2004).

Health and well-being Assets theory can be defined as the crucial building blocks for promoting healthy youth development and well-being (Benson, 1997; Benson, Leffert, Scales, \& Blyth, 1998). Health and well-being Assets theory refers both to internal and external strengths (Kia-Keating et al., 2009). A lack of assets can be directly related to a person's failure to thrive, but is only indirectly related to behaviour problems (Small \& Memmo, 2004).

The expression Positive Youth Development (PYD) has been used at least in three ways: as a description of the natural developmental process of children and adolescents, as a unifying philosophy characterized by a positive asset-building orientation, and finally as a category of programs that provide activities to promote youth development and thriving (Hamilton, 1999; Whitlock \& Hamilton, 2001).

The PYD approach is grounded on the assumptions that the best way to prevent youths from experiencing problems is to help them to achieve their full potential and, for this purpose, they need to experience various supports and opportunities. In order to promote these opportunities, the communities need to activate and to strengthen the capacity to support the positive development of youth and to view youths as partners to be involved and not just as problems to be fixed (Pittman, Irby, Tolman, Yohalem, \& Ferber, 2003), which mean safe places, challenging experiences, and caring people (Zeldin, Kimball, \& Price, 1995). This approach has a strong effect on intervention strategies, listening and 
involving the target populations (Matos \& Simóes, 2016; Matos, 2019; Benard \& Slade, 2009).

\section{Models of Youth Development}

Contemporary models of youth development and problem prevention can be generally grouped into one of three types: prevention, resilience, and positive youth development. Each of these approaches give a unique contribution to the knowledge on coping, development, human adaptation and thriving, and they all share several key features, and a common vision focused on improving the life of youths. Each approach addresses a specific part of a comprehensive youth development strategy, and no single approach is fully satisfactory for the several challenges, given the complexity of the human development, the diversity of youths and of their families and the dynamic nature of life in community (Small \& Memmo, 2004).

\section{PREVENTION APPROACHES}

This approach was based on the idea that it is more cost-effective and efficient to prevent problems from occurring than to treat them after they occur. Prevention can be differentiated into three intervention subcategories (Gordon, 1987): Universal (directed at an entire population), Selective (directed at a subgroup of a population in risk of developing a problem) and Indicated (targeted at high-risk individuals who show some signs of a problem).

The prevention approach aims to reduce/eliminate risk factors and increase/ promote protective factors, enhancing the strengths, skills, or competencies of the target group, so they are better able to cope with challenges (Durlak, 1997).

This approach has some limitations, such as it tends to be deficit-oriented emphasizing youth problems (Benson, 1997; Pittman \& Cahill, 1991).

\section{RESILIENCE APPROACHES}

The primary aim of resilience research has been to identify and understand the factors that distinguish individuals who demonstrate a good adaptation ability when confronted with adversity, from those who don't. Two conditions must prevail for resilience to exist: the experience of extreme stress and the manifestation of successful adaptation or competence to cope, despite such stress (Masten, 2001; Rutter, 1987; Werner, 1993).

The concept of Resilience has primarily tried to elucidate the process of healthy development in face of significant life adversities (Luthar, Cicchetti, \& Becker, 2000; Luthar, 2006; Rutter, 1987). The adaptation responses are quite different among adolescents depending on specific individual and contextual factors, and can be compromised when risks are cumulative, specifically when problems are 3 or more (Rutter, 1979; Simóes, Matos \& Morgan, 2015). 
The concept of resilience (Rutter, 1987; Rutter,1979; Masten, 2001) implies thus a (balanced) reaction to an adversity, therefore it implies the previous existence of that adversity. Over the last couple of years, such a useful concept was unfortunately used and disseminated in such an excessive way, that it lost much of its usefulness and even partially of its sense. When there is no previous situation of substantial adversity, the concept of Positive Development is more accurately used (Kia-Keating et al, 2010). Positive Development has highlighted the importance of strengthening internal and external developmental assets within adolescent's networks and opportunities (Catalano, Berglund, Ryan, Lonczak, \& Hawkins, 2004; Lerner, Fisher, \& Weinberg, 2000; Roth \& Brooks-Gunn, 2003; Small \& Memmo, 2004).

More recently, resilience was distinguished from coping. Coping emphasizes the identification of the specific cognitive and behavioural efforts employed to manage a stressful situation (Ayers, Sandler, \& Twohey, 1998), whereas resilience focuses on identifying stable characteristics in the child or in his/her environment, that help him/her deal with stressful situations or to recover or adapt (Masten, 2001).

The main criticisms to the resilience approaches are based on the fact that they can result in a tendency to neglect environmental conditions (Tolan, 1996) and overemphasize the individual, thus reducing the effects of contextual risks. Another major criticism is due to the overuse of this concept that, as said, is very specific and implies dealing with stressful situations or to recovery (Masten, 2001).

\section{The Positive Youth DeVELOPMENT (PYD) APPROACH}

A recent approach that highlights the positive aspects of youth development and health, has emerged among professionals and policy-makers and emphasizes the promotion of positive development and the conditions contributing to youth health and well-being, suggesting that preventing problems is not enough to prepare youth for adulthood (Roth, Brooks-Gunn, Murray, \& Foster, 1998). The Search Institute's Developmental Assets model (Benson, 1997) has identified 40 relevant developmental assets, defined as crucial building blocks for promoting healthy youth development and well-being (Benson, Leffert, Scales, \& Blyth, 1998; Scales \& Leffert, 1999; Benson et al., 2006). Such assets seek to help young people to grow up healthy, caring and responsible. The 40 assets were organized into two major blocks, each one comprising 4 categories: External Assets (Support, Empowerment; Boundaries and Expectations, and Constructive Use of Time) and Internal Assets (Commitment to Learning; Positive Values; Social Competencies and Positive Identity). This framework brought evidence on the relationship between youth developmental assets and measures of well-being as a universal 
occurrence, supporting, thus, the efforts to globally build developmental assets as a positive youth development strategy (Scales, Roehlkepartain, \& Fraher, 2012).

Responses to the "deficit perspective" made another major approach emerge, based on a categorization of 5 Competences/5Cs: Competence; Confidence; Character; Connection and Caring (Lerner, Phelps, Forman, \& Bowers, 2009; Lerner et al., 2013; Lerner et al., 2011a) Lerner et al, 2011. b). The 5Cs is a strength-based approach that moves towards a vision that youth are resources to be developed and nurtured. It focuses on the relation between youth's strengths and resources in their surrounding settings, as the key of promoting positive outcomes (Lerner et al., 2009; Pittman, Irby, Tolman, Yohalem, \& Ferber, 2003). Several measures were used to index PYD (Lerner et al., 2005), operationalized through the assessment of Five Cs: Competence (in academics, social, emotional and vocational areas); Confidence (in who the individual is becoming - own identity); Character (related to positive values, integrity, and a strong sense of morality); Connection (ties to self and others); and Caring (empathy and compassion).

The Five Cs are hypothesized as a way of conceptualizing PYD, relying on the experiences of practitioners and on the literature reviews of adolescent's development (Eccles \& Gootman, 2002; Lerner, 2004; Roth \& Brooks-Gunn, 2003), and a healthy development of all of them is required for PYD (Dukakis et al., 2009). Its manifestation through adolescence can increase a mutuallybeneficial person/context relationship later in life's trajectory, and if so, a sixth C may emerge - Contribution (social engagement and social participation) (Lerner, 2004). PYD is associated with positive indicators such as contribution, school engagement, successful intentional self-regulation, and hope (Geldhof et al., 2014).

Integrative models of Positive Development

Resilience (Rutter, 1987) and Positive Youth development (Benson, 1998; Lerner, Fisher \& Weinberg, 2000) share principles, have substantial overlap and offer complementary perspectives. Therefore, an integrative model was needed, including research and practical applications (Schwartz et al., 2007).

Recently, a model based on a unified approach of these concepts was developed (Kia-Keating, et al, 2010), having the potential benefit of the interconnectedness of risk, protection, and assets, within the ecosystems affecting adolescent development. The model presents two pathways: on one hand, the "Protecting" pathway, drawn from the resilience research, comprising risk and protection and implying previous adversity; and, on the other, the "Promoting" pathway, drawn from the positive youth development research, including the assets. In the first pathway, protection moderates the relationship between risk and healthy development. In the second pathway, assets lead directly to healthy 
development, despite having a reciprocal relationship with risk, and assuming that assets can prevent the occurrence of risk. Individual, family, school, community and cultural factors were included in this model and thought to influence the entire system (Bronfenbrenner, 1979; Bronfenbrenner \& Morris, 2006). This model delineates eight developmental domains (Kia-Keating et al., 2010), seven of which are derived from categories previously emphasized in applied research (Benson, 2003; Eccles \& Gootman, 2002; Lerner, Fisher \& Weinberg, 2000), and an additional eighth domain (self-regulation) that has been highlighted as a potential target area in interventions (Webster-Statton, Reid, \& Stoolmiller, 2008). The model also displays the reciprocal interactions between adolescents and their social networks and ecological settings (Eccles, Early, Frasier, Belansky, $\&$ McCarthy, 1997) that can promote thriving (Gestsdóttir et al, 2011). These eight developmental domains that are target areas for interventions as well as key outcomes of healthy development and thriving (Kia-Keating, 2009; Kia-Keating et al., 2010) comprise the following areas: Social, promoting social support, bonding, and sense of belonging; Emotional, supporting self-efficacy and resilience-building; Behavioural, involving youth in prosocial activities; Moral, character-building through the fostering of prosocial norms; Physiological, building self-regulation skills and allowing the transaction between adolescents and their ecological contexts and promoting thriving; Cognitive, perspective-building by supporting youth to develop a broader awareness of meaning, hope and purpose in their lives; Educational, competence-building through activities that provide youth with new skills and point out the importance of school engagement; Structural, ensuring structure and safety and including adult supervision and monitoring.

Another recent framework for understanding behaviour was proposed and named the Behaviour Change Wheel Model (BCW) (Michie, van Stralen, \& West, 2011). This model has as a starting-point the question of what causes behavioural change (Michie, van Stralen \& West, 2011), or in other words, and as phrased in PYD: which personal and environmental match fits better human thriving?

The BCW model was based on theoretical and evidenced-based knowledge, matching interventions with specific behaviour to be achieved, and matching the target-populations with the contexts. This process must be coherent and aligned with in relationship with the specific mechanisms of behavioural change. This system was named the COM-B system and suggests that for behavioural change to happen, at least three components are needed, namely: Capacity, the physical and psychologic skills for behaviour change, mainly knowledge and competence; Motivation, the intention to act, which includes emotional and impulsive processes, as well as a reflexive process of decision making; and Opportunity, within the context, whose external factors must allow behaviour action.

In an attempt to fill in the gap between the COM-B system and other perspectives within the PYD framework, capacity and motivation factors necessary 
for intentionalself-regulation come to the surface, thus becoming essential features for thriving (Gestsdóttir et al, 2012).

Concerning Opportunities, these are in great part derived from external factors. Yet, the concept of Affordances may prove to be helpful here (Gibson, 1979; Araújo et al., 2019). Affordances are the capacities that must be developed, in order to identify, create and use external opportunities. According to the affordances' perspective, higher performers present greater affordances in order to fully enjoy environmental opportunities. That is to say, affordances allow people to perceive opportunities for action and to develop intentional self-regulation, so that they can make use of these opportunities,

Another conceptual framework relevant and inspiring to understand thriving is the SOC model - Selection, Optimization and Compensation (Baltes, 1997), applied to a lifespan perspective by Geldhof et al. (2014). These authors argue that the capacity to select, optimize and compensate areas of interest and of competence, from a lifespan perspective, is related to that possibility of perceiving opportunities, making the adequate choices and increasing people thriving.

The BCW model (Michie et al., 2011) emphasizes a distinction between Interventions, or activities which aim to achieve behavioural changes, and Policies, or politic actions that allow and support interventions. Nine interventions are suggested within BCW, namely Education, Persuasion, Incentivization, Coercion, Training, Enablement, Modeling, Environmental Restructuring and Restrictions. Moving to a larger perspective, seven types of policies are to be considered, specifically Communication/Marketing, Legislation, Service Provision, Regulation, Fiscal Measures, Guidelines and Environmental/Social Planning.

The $\mathrm{BCW}$ model reinforces the context (corresponding to the component Opportunity) as a key factor for the design and implementation of effective interventions, although, as was already pointed out, opportunities can be also read as the "opportunities that can be perceived and identified, used and kept" (Michie et al., 2011), therefore including individual factors, namely affordances and intentional self-regulation. Therefore, individual behaviour can be only understood in relation to the social, physical and digital context, and both are the starting point for planning interventions.

\section{Positive Youth Development: Affordances, SOC, Intentional} Self-Regulation and Thriving

During childhood and adolescence, the ability to regulate actions is progressively developing (self-regulation capacity), which implies adjustments to the context and vice-versa, thus an interactive bi-directional process (Gestsdóttir \& Lerner, 2008). In children/adolescents, intentional self-regulation refers to various capacities, such as quickly switch between different tasks, focus attention or emotional control (smooth balance). PYD approaches can help youth to 
develop capacities for intentional self-regulation and protectors from engagement in risk behaviours, such as substance use and violence (Bonell et al., 2016). It enables youth to reflect on their behaviours, to select personal goals and to apply the necessary resources to pursue them, including compensation or re-selection strategies, if goals are not achieved (Benson, 2007).

The SOC model (selection, optimization and compensation) was successfully applied across lifespan and related to the possibility of thriving (Geldorf et al: 2014). Thriving occurs when individual and context relations involve the coexistence between people strengths and the resources of their contexts (Gestsdóttir, et al: 2011). PYD promotes positive interactions between individuals and their environments, affective relations and several opportunities for developing positive assets (Lerner, et al: 2011a) b); Schwartz, Pantin, Coatsworth, \& Szapocznik, 2007). Affordances allow individuals to perceive and identify existing opportunities and to make use of them for better performances (Araújo et. al., 2019).

The development of these positive attributes can promote improved self-care, greater academic achievement, higher quality in interpersonal relationships and overall improvements in well-being, not only in adolescence, but also across the lifespan (Maslow \& Chung, 2014), by adopting a lifespan approach, a participative approach, and an intergenerational perspective.

\section{Positive Human Development: Openness, Curiosity and Flexibility}

Associated to promoting health, positive development and thriving comes the concept of well-being and the question of to what extent well-being can be promoted towards preventive or promotional large population-based interventions, as for example, in workplaces and in schools. This aspect has also a powerful message to public policies that often disregard well-being as an important feature of health, highlighting the relevance of increasing the populations' well-being, as for instance, through valuing, promoting and maintaining larger degrees of choice (degrees of liberty for choosing).

Considering younger populations, it is well established that effective youth programs include youth participation (opportunities for youth participation and leadership), skills building (emphasis on the development of life skills) and adult mentorship (a context of sustained and caring adult-youth relationships) (Lerner, Lerner, Almerigi, et al., 2006).

From a rather different area of research, Hayes, Strosahl, \& Wilson (2012) have described how internal language (self-talk) can alter well-being, increasing or reducing openness and psychological flexibility. Language can "open minds" but it can also "close minds" (Matos, 2020). Hayes et al., (2012) have used the Hexaflex model to identify six processes that can increase or reduce Psychological Flexibility depending on the individual capacity to shift among these six processes in an open, curious and flexible manner: Values (what is important); Directions 
(steps towards what is important); Inner self(being close to and aware of oneself); External contexts (being aware of and open to external perceptions and sensations); Self-acceptance (being aware and acceptant towards oneself) and Diffusion (being aware and able to recognise thoughts and emotions, without being flooded by them).

While crossing decades of rapid changes, being able (or identifying opportunities) to thrive, being capable of a smooth and intentional self-regulation, without feeling "irrelevant" when facing internal or external challenges is associated to being able to deal with all opportunities for diversity and change, and still maintaining and developing competence, motivation, curiosity, and openness to changes and psychological flexibility (Matos, 2020).

\section{REFERENCES}

Ayers, T. S., Sandler, I. N., \& Twohey, J. L. (1998). Conceptualization and measurement of coping in children and adolescents. In T. H. Ollendick \& R. J. Prinz (Eds.), Advances in Clinical Child Psychology, Vol. 20 (pp. 243-301). New York: Plenum Press.

Baltes, P.B. (1997). On the incomplete architecture of human ontogeny: Selection, optimization, and compensation as foundations of developmental theory. American Psychologist, 52, 366- 380.

Benard, B., \& Slade, S. (2009). Listening to students: Moving from resilience research to youth development practice and school connectedness. In R. Gilman, E. S. Huebner, \& M.J. Furlong (Eds.), Handbook of positive psychology in the schools (pp. 353-370). New York: Routledge.

Benson, P.L. (2007). Developmental assets: an overview of theory, research and practice. In: R.K. Silbereisen \& R.M. Lerner (Eds.), Approaches to Positive Youth Development (pp. 33-58). Thousand Oaks: Sage.

Benson, P.L. (2003). Developmental assets and asset-building community: Conceptual and empirical foundations. In R. Lerner, P.L. Benson (Eds.) Developmental Assets and Asset-Building Communities: Implications for Research, Policy, and Practice (pp. 19-43). New York, NY: Kluwer Academic/Plenum.

Benson, P. (1997). All kids are our kids: What communities must do to raise caring and responsible children and adolescents. San Francisco: Jossey-Bass

Benson, P., Leffert, N., Scales, P., \& Blyth, D. (1998). Beyond the village rhetoric: Creating healthy communities for children and adolescents. Applied Developmental Science, 2, 138-159.

Benson, P. L., Scales, P. C., Hamilton, S. F., Sesma, A. (2006). Positive Youth development: Theory, research and application. In W. Damon, \& R. M., 
Lerner (Eds.), Handbook of Child Psychology, (6th ed., pp. 894-941). New York: Wiley.

Bonell, C., Hinds, K., Dickson, K., Thomas, J., Fletcher, A., Murphy, S., Melendez-Torres, G. J., Bonell, C., \& Campbell, R. (2016). What is positive youth development and how might it reduce substance use and violence? A systematic review and synthesis of theoretical literature. BMC Public Health, 16, 135. doi: 10.1186/s12889-016-2817-3

Branquinho, C., \& Matos, M. G. (2018). Why "Dream Teens": was there an impact after a two-year participatory action-research program? Child Indicators Research, 12, 1243-1257. doi: 10.1007/s12187-018-9585-9

Bronfenbrenner, U., \& Morris, P.A. (2006). The bioecological model of human development. In: R. M. Lerner \& W. Damon (Eds.) Handbook of Child Psychology, Volume 1: Theoretical Models of Human Development, pp. 793-828. Hoboken, NJ: John Wiley \& Sons.

Bronfenbrenner, U. (1979). The Ecology of Human Development: Experiments by Nature and Design. Cambridge, MA: Harvard University Press.

Catalano, R. F., Berglund, M. L., Ryan, J. A. E., Lonczak, H. S., \& Hawkins, J.D. (2004). Positive youth development in the United States: Research findings on evaluations of positive youth development programs. The Annals of the American Academy of Political and Social Science, 591, 98. doi: 10.1177/0002716203260102

Araújo, D., Hristovski, R., Seifert, L., Carvalho, J., \& Davids, K. (2019). Ecological cognition: Expert decision-making behaviour in sport. International Review of SportandExercise Psychology, 12, 1-25.doi: 10.1080/1750984X.2017.1349826.

Dukakis, K., London, R. A., McLaughlin, M., \& Williamson, D. (2009). Positive youth development: Individual, setting and system level indicators. (Issue brief: Positive youth development indicators). Stanford, CA: John W. Gardner Center for Youth and Their Communities.

Durlak, J. A. (1997). Successful Prevention Programs for Children and Adolescents. New York, NY: Plenum Press.

Eccles, J. S., Early, D., Frasier, K., Belansky, E., \& McCarthy K. (1997). The relation of connection, regulation, and support for autonomy to adolescents' functioning. Journal of Adolescent Research, 12, 263-86.

Eccles, J., \& Gootman, J. (eds.) (2002). Community Programs to Promote Youth Development. Washington, DC: National Academies Press.

Geldhof, G. J. Bowers, E. P., Gestsdóttir, S., Napolitano, C. M., Schmid, K., \& Lerner, R.M. (2014). Self-regulation across Adolescence: Exploring the 
structure of Selection, Optimization and Compensation. Journal of Research on Adolescence, 24, 1-15. doi: 10.1111/jora.12131

Gestsdóttir, S., Urban, J., Bowers, E.; Lerner, J., \& Lerner, R. M. (2011) Intentional self-regulation, ecological assets and thriving in adolescence: a developmental systems model in R. M. Lerner, E. P. Bowers, S. Lewin-Bizan, S. Gestsdóttir \& J. B. Urban (Eds), Thriving in childhood and adolescence. The role of self -regulation processes. New Directions for Child and Adolescents Development, 133, 61-79

Gestsdóttir, S., \& Lerner, R. M. (2008). Positive development in adolescence: The development and role of intentional self-regulation. Human Development, 51, 202-224.

Gibson, J. J. (1979) The ecological approach to visual perception. Boston, MA: Houghton Mifflin

Gordon, R. (1987). An operational classification of disease prevention. In J. A. Steinberg, \& M. M. Silverman (Eds.) Preventing mental disorders (pp. 20-26). Rockville, MD: Department of Health and Human Services.

Hamilton, S. F. (1999). A three-part definition of youth development. Unpublished manuscript, Cornell University College of Human Ecology, Ithaca NY.

Hayes, S. C., Strosahl, K. D., \& Wilson, K.G. (2012). Acceptance and commitment therapy: the process and practice of mindful change. New York: Guilford.

Kia-Keating, M. (2009). Positive psychology and school/community-based youth participatory photography programs. In R. Gilman, E. S. Huebner, \& M. J. Furlong (Eds.) Handbook of Positive Psychology in Schools, pp. 383-397. New York, NY: Taylor \& Francis.

Kia-Keating, M., Dowdy, E. Morgan, M., \& Noam, G. (2010). Protecting and Promoting: An Integrative Conceptual Model for Healthy Development of Adolescents. Journal of Adolescent Health, 48, 220-228. doi:10.1016/j. jadohealth.2010.08.006

Lerner, R. M. (2004). Liberty: Thriving and civic engagement among American youth. Thousand Oaks, CA: Sage.

Lerner, J.V., Bowers, E. P., Minor, K., Boyd, M. J., Mueller, M. K., Schmid, K. L., Napolitano, C. M., Lewin-Bizan, S., \& Lerner, R. M. (2013). Positive youth development: Processes, philosophies, and programs. In R. M. Lerner, M.A., Easterbrooks, \& J. Mistry (Eds.), Handbook of Psychology, Volume 6: Developmental Psychology (2nd Edition) (pp. 365-392). Hoboken, NJ: Wiley.

Lerner, R. M., Lerner, J. V., Lewin-Bizan, S., Bowers, E. P., Minor, K., Boyd, M. J., Mueller, M. K., Schmid, K. L., \& Napolitano, C. M. (2011b). Positive 
youth development: Processes, programs and problematics, Journal of Youth Development, 6 (3), 41-64.

Lerner, R. M., Lerner, J. V., von Eye, A., Bowers, E. P., \& Lewin-Bizan, S. (2011a). Individual and contextual bases of thriving in adolescence: A view of the issues. Journal of Adolescence, 34, 1107-14.

Lerner, J. V., Phelps, E., Forman, Y., \& Bowers, E. P. (2009). Positive youth development. In R. M. Lerner, L. Steinberg, R. M. Lerner, \& L. Steinberg (Eds.), Handbook of adolescent psychology, Vol 1: Individual bases of adolescent development (3rd Ed.) (pp. 524-558). Hoboken, NJ US: John Wiley \& Sons Inc.

Lerner, R. M., Fisher, C. B., \& Weinberg, R. A. (2000). Toward a science for and of the people: Promoting civil society through the application of developmental science. Child Development, 71, 11-20.

Lerner, R. M., Almerigi, J., Theokas, C., \& Lerner, J. V. (2005). Positive youth development: A view of the issues. Journal of Early Adolescence, 25, 10-16.

Lerner, R. M., \& Lerner, J. V., Almerigi, J., \& et al. (2006). Toward a new vision and vocabulary about adolescence: theoretical, empirical, and applied bases of a 'positive youth development' perspective. In, L. Balter, \& C. S. TamisLeMonda (Eds.). Child psychology: A handbook of contemporary issues, pp. 44569, 2nd ed. New York: Psychology Press.

Luthar, S. S., Cicchetti, D., \& Becker, B. (2000). The construct of resilience: A critical evaluation and guidelines for future work. Child Development, 71(3), 543-62.

Luthar, S. S. (2006). Resilience in development: A synthesis of research across five decades. In, D. Cicchetti, \& D. J. Cohen (Eds.). Developmental Psychopathology, pp. 739-395. Hoboken, NJ: John Wiley.

Maslow, G., \& Chung, R. (2014). Systematic Review of Positive Youth Development Programs for Adolescents with Chronic Illness. Pediatrics, 131, 5(e1605-e1618). doi: 10.1542/peds.2012-1615

Masten, A. S. (2001). Ordinary magic: Resilience processes in development. American Psychologist, 56, 227-38.

Matos, M. G. (2020). É mesmo Importante? Lisboa: OPP.

Matos, M. G. (2019). Dream teens: Navigating life like a protagonist throughout adolescents, Lambert Ac. Publishing.

Matos, M. G., \& Simóes, C. (2016). From Positive Youth Development to Youth's Engagement: The Dream Teens. The International Journal of Emotional Education, 8 (1), 4-18. 
Matos, M. G., Branquinho, C., Cruz, J., Tomé, G., Camacho, I., Reis, M., Equipa Aventura Social (2015). Dream Teens: Adolescentes autónomos, responsáveis e participantes. Revista de Psicologia da Criança e do Adolescentel Journal of Child and Adolescent Psycology, 6 (2), 47-58.

Mitchie, S., Stralen, M., \& West, R. (2011). The Behaviour Change Wheel: A new method for characterising and designing behaviour change interventions. Implementation Sciences, 6, 42. doi: 10.1186/1748-5908-6-42

Moore, K. A., Lippman, L., \& Brown, B. (2004). Indicators of child wellbeing: The promise for Positive Youth Development. Annals of the American Academy of Political and Social Science. Special Issue: Positive Development: Realizing the Potential of Youth, 591, 125-145.

Pittman, K., \& Cahill, M. (1991). A new vision: Promoting youth development. Washington, DC: Academy for Educational Development, Center for Youth Development and Policy Research.

Pittman, K. J., Irby, M., Tolman, J., Yohalem, N., \& Ferber, T. (2003). Preventing Problems, Promoting Development, Encouraging Engagement: Competing Priorities or Inseparable Goals?. Based upon K. Pittman, \& M. Irby (1996). Preventing Problems or Promoting Development? Washington, DC: The Forum for Youth Investment, Impact Strategies, Inc. Available online at www. forumfyi.org.

Roth, J., Brooks-Gunn, J., Murray, L., \& Foster, W. (1998). Promoting healthy adolescents: Synthesis of youth development program evaluations. Journal of Research on Adolescence, 8 (4), 423-459.

Roth, J. L., \& Brooks-Gunn, J. (2003). Youth development programs: risk, prevention and policy. Journal of Adolescent Health, 32, 170-82.

Rutter, M. (1987). Psychosocial resilience and protective mechanisms. American Journal of Orthopsychiatry, 57, 316-31.

Rutter, M. (1979). Protective factors in children's responses to stress and disadvantage. In M. Kent \&J. Rolf(Eds.), Primaryprevention of psychopathology, Vol. 3: Social competence in children. Hanover, NH: University Press of New England.

Scales, P., \& Leffert, N. (1999). Developmental assets: A synthesis of the scientific research on adolescent development. Minneapolis, MN: Search Institute.

Scales, P., Roehlkepartain, E., \& Fraher, K. (2012). Do Developmental Assets Make a Difference in Majority-World Contexts? A Preliminary Study of the Relationships Between Developmental Assets and Selected International Development Priorities. Education Development Center, Inc. Search Institute. 
Schwartz, S. J., Pantin, H., Coatsworth, J. D., \& Szapocznik, J. (2007). Addressing the challenges and opportunities for today's youth: toward an integrative model and its implications for research and intervention. The Journal of Primary Prevention, 28(2), 117-44.

Simóes, C., Matos, M. G., \& Morgan, A. (2015). Facing the adversity: The role of internal assets on wellbeing in adolescents with special needs. Spanish Journal of Psychology, 18(e56), 1-14. doi: 10.1017/sjp.2015.41

Small, S., \& Memmo, M. (2004). Contemporary Models of Youth Development and Problem Prevention: Toward an Integration of Terms, Concepts, and Models. Family Relations, 53, 3-11. doi: 10.1111/j.1741-3729.2004.00002.x

Tolan, P. (1996). How resilient is the concept of resilience? The Community Psychologist, 29, 12-15.

Webster-Stratton, C., Reid, M. J., \& Stoolmiller, M. (2008). Preventing conduct problems and improving school readiness: Evaluation of the incredible years' teacher and child training programs in high risk schools. Journal of Child Psychology and Psychiatry, 49, 471-88.

Werner, E. (1993). Risk, resilience, and recovery: Perspectives from the Kauai Longitudinal Study. Development and Psychopathology, 5, 503-515.

Whitlock, J., \& Hamilton, S. (2001). Youth development principles and practices: Defining what it is and is not. Ithaca, NY: Unpublished manuscript, Department of Human Development, Cornell University.

Zeldin, S., Kimball, M., \& Price, L. (1995). What are the day-to-day experiences that promote youth development?: An annotated bibliography of research on adolescents and their families. Washington, DC: Academy for Educational Development, Center for Youth Development and Policy Research. 